This item was submitted to Loughborough's Research Repository by the author.

Items in Figshare are protected by copyright, with all rights reserved, unless otherwise indicated.

\title{
Activity profiles of elite wheelchair rugby players during competition [erratum]
}

PLEASE CITE THE PUBLISHED VERSION

http://dx.doi.org/10.1123/ijspp.2014-0203

\section{PUBLISHER}

(c) Human Kinetics

\section{VERSION}

VoR (Version of Record)

\section{PUBLISHER STATEMENT}

This work is made available according to the conditions of the Creative Commons Attribution-NonCommercialNoDerivatives 4.0 International (CC BY-NC-ND 4.0) licence. Full details of this licence are available at: https://creativecommons.org/licenses/by-nc-nd/4.0/

\section{LICENCE}

CC BY-NC-ND 4.0

\section{REPOSITORY RECORD}

Rhodes, James M., Barry S. Mason, Bertrand Perrat, Martin J. Smith, Laurie A. Malone, and Victoria L. Goosey-Tolfrey. 2019. "Activity Profiles of Elite Wheelchair Rugby Players During Competition [erratum]". figshare. https://hdl.handle.net/2134/20792. 


\section{Erratum: Rhodes et al (2015)}

The character for "less than/equal to" $(\leq)$ was printed incorrectly in this article. In text-twice on p. 319, twice on p. 320, and once on p. 323-it appears as a small box with an "X" in it (囚). Five times in Table 3, on p. 320, it appears as the British pound sign (£). 